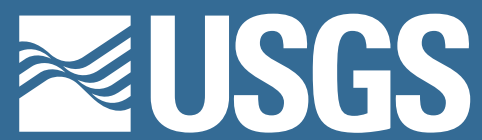

Prepared in cooperation with the St. Regis Mohawk Tribe-Environment Division

\title{
Dam Removal, Connectivity, and Aquatic Resources in the St. Regis River Watershed, New York
}

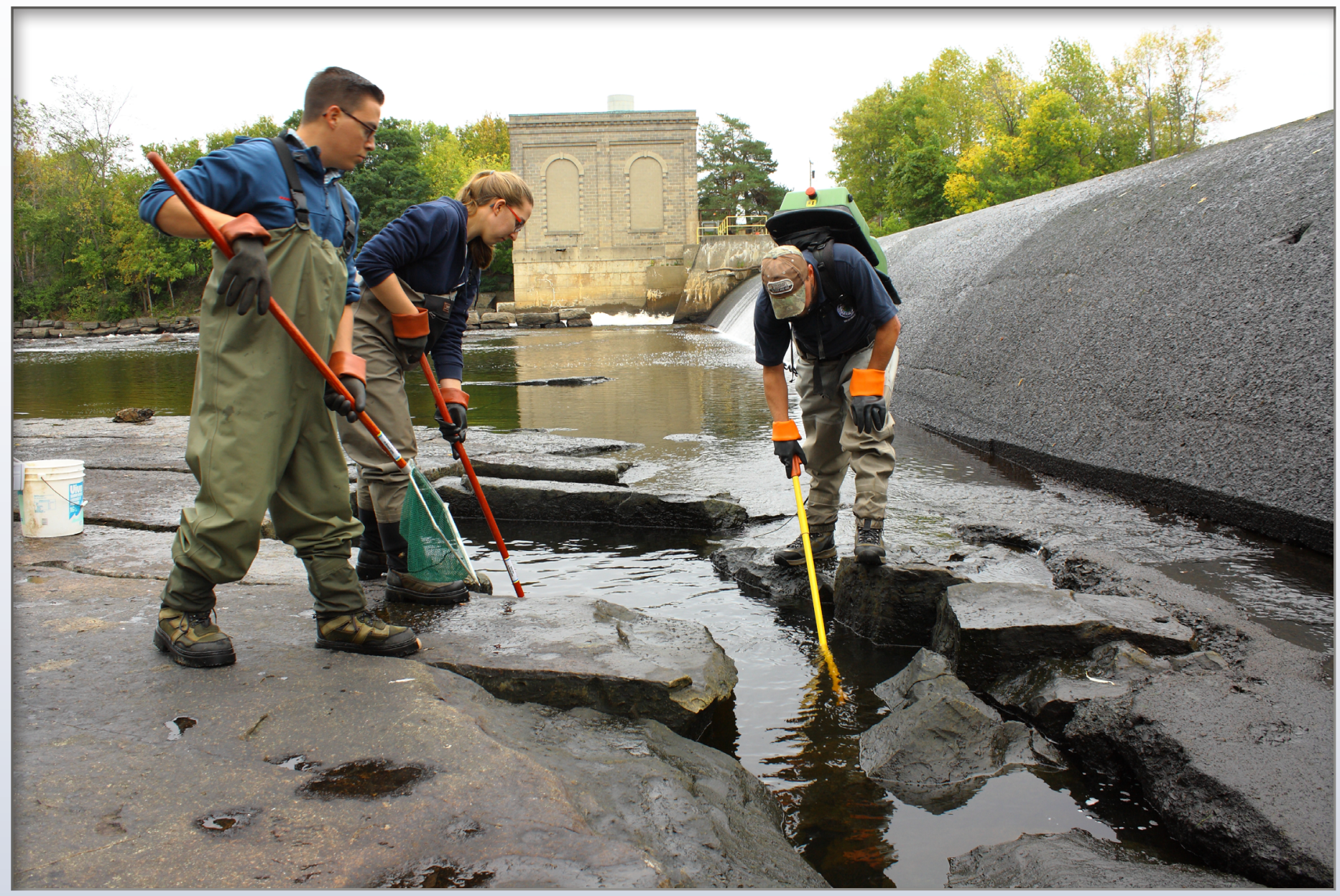

Scientific Investigations 2015-5116 
Cover photograph. USGS Aquatic Ecology Technician, Emma Mrowka; Mohawk Tribe Water Quality Technician, Dylan Herne; and Fish and Wildlife Technician, Jay Wilkins. This photo was provided by the St. Regis Mohawk Tribe-Environmental Division. 


\section{Dam Removal, Connectivity, and Aquatic Resources in the St. Regis River Watershed, New York}

By James E. McKenna, Jr., Kaitlin Hanak, Katharine DeVilbiss, Anthony David, and James H. Johnson

Prepared in cooperation with the St. Regis Mohawk Tribe-Environment Division

Scientific Investigations Report 2015-5116 


\title{
U.S. Department of the Interior SALLY JEWELL, Secretary
}

\section{U.S. Geological Survey \\ Suzette M. Kimball, Acting Director}

\author{
U.S. Geological Survey, Reston, Virginia: 2015
}

For more information on the USGS - the Federal source for science about the Earth, its natural and living resources, natural hazards, and the environment—visit http://www.usgs.gov or call 1-888-ASK-USGS.

For an overview of USGS information products, including maps, imagery, and publications, visit http://www.usgs.gov/pubprod/.

Any use of trade, firm, or product names is for descriptive purposes only and does not imply endorsement by the U.S. Government.

Although this information product, for the most part, is in the public domain, it also may contain copyrighted materials as noted in the text. Permission to reproduce copyrighted items must be secured from the copyright owner.

Suggested citation:

McKenna, J.E., Jr.; Hanak, Kaitlin; DeVilbiss, Katharine; David, Anthony; and Johnson, J.H., 2015, Dam removal, connectivity, and aquatic resources in the St. Regis River watershed, New York: U.S. Geological Survey Scientific Investigations Report 2015-5116, 15 p., http://dx.doi.org/10.3133/sir20155116.

ISSN 2328-0328 (online) 


\section{Acknowledgments}

This study was conducted in cooperation with the St. Regis Mohawk Tribe (SRMT)-Environment Division. The authors thank the members of the SRMT, as well as Emma Mrowka, for assistance with field collections. The authors also thank Robert Alexander and Michael Slattery for their assistance with geographic information system data and Heather Galbraith for her assistance with native mussel identification. Lastly, the authors thank the private land owners in the study area for their cooperation. This research was funded by the U.S. Geological Survey (USGS)Ecosystem Program. Substantial support was provided by the USGS-Great Lakes Regional Aquatic Gap Analysis Project. 



\section{Contents}

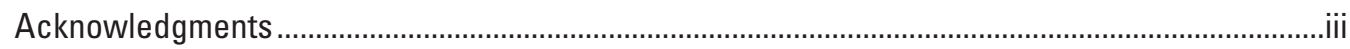

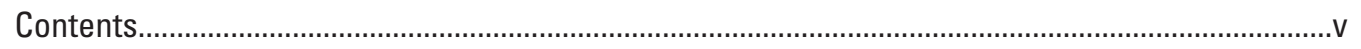

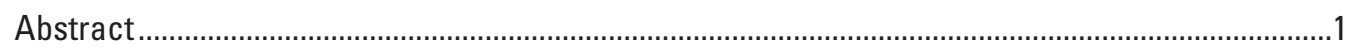

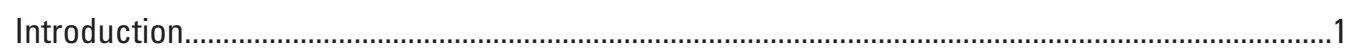

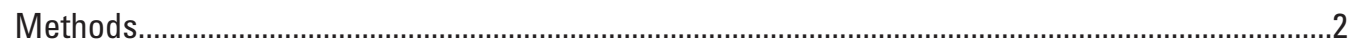

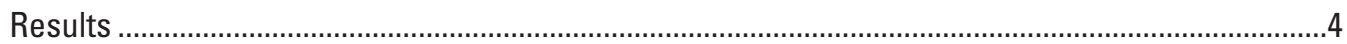

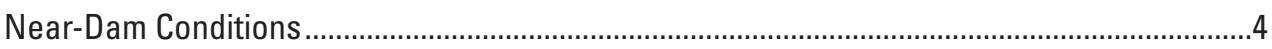

Measuring the Effects of Dam Removal ...........................................................................

Headwater Conditions ........................................................................................................

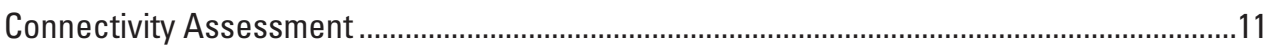

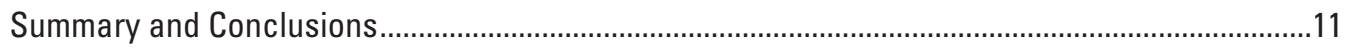

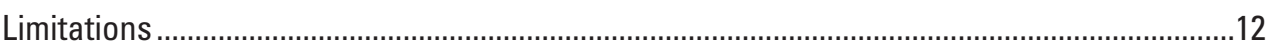

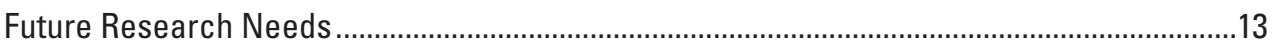

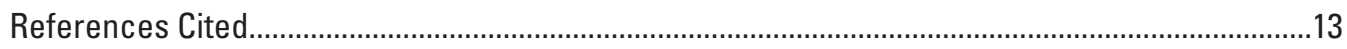

Appendix 1. Fish Species Code Definitions........................................................................

\section{Figures}

1. Map showing St. Regis subwatersheds, observed and U.S. Geological Survey-Great Lakes Regional Aquatic Gap Analysis Project (GLGap) predicted suitability of Brook Trout habitat, and actual Brook Trout abundance at labeled sample sites

2. Map showing sites sampled and predicted water levels in the reservoir following removal of the Hogansburg Dam, Franklin County, New York ...........................5

3. Vertical graph of species assemblage based on sample sites near the Hogansburg Dam, Franklin County, New York.

4. Graph showing habitat characteristics affecting Brook Trout abundance near Hogansburg Dam, Franklin County, New York.

\section{Tables}

1. Species richness of sample site catches near Hogansburg Dam, Franklin County, New York...

2. Estimated surface areas, volumes of water, and exposed reservoir bed above the Hogansburg Dam, Franklin County, New York.

3. Sampling efficiency for 1-pass electrofishing for sufficiently calculating species abundance near Hogansburg Dam, Franklin County, New York.

4. Fish catch per unit effort (CPUE; standardized abundance in units of fish 100 square meters), species richness (number of species present), species diversity (Shannon-Weaver information index; Shannon and Weaver, 1949), and evenness (index of the distribution of total abundance among species present) of fish assemblages in headwater sites near Hogansburg Dam, Franklin County, New York.

5. Multiple linear regression of Brook Trout abundance as a function of altitude, water temperature, and stream size 


\section{Conversion Factors}

International System of Units to Inch/Pound

\begin{tabular}{lcl}
\hline \multicolumn{1}{c}{ Multiply } & By & \multicolumn{1}{c}{ To obtain } \\
\hline & Length & \\
meter $(\mathrm{m})$ & 3.281 & foot $(\mathrm{ft})$ \\
kilometer $(\mathrm{km})$ & 0.6214 & mile (mi) \\
kilometer $(\mathrm{km})$ & 0.5400 & mile, nautical (nmi) \\
meter $(\mathrm{m})$ & 1.094 & yard (yd) \\
\hline & Area & acre \\
\hline square meter $\left(\mathrm{m}^{2}\right)$ & 0.0002471 & acre \\
square kilometer $\left(\mathrm{km}^{2}\right)$ & 247.1 & square foot $\left(\mathrm{ft}^{2}\right)$ \\
square meter $\left(\mathrm{m}^{2}\right)$ & 10.76 & square mile $\left(\mathrm{mi}^{2}\right)$ \\
square kilometer $\left(\mathrm{km}^{2}\right)$ & 0.3861 & \\
\hline & Volume & gallon $(\mathrm{gal})$ \\
cubic meter $\left(\mathrm{m}^{3}\right)$ & 264.2 & million gallons $\left(\mathrm{Mgal}^{2}\right)$ \\
cubic meter $\left(\mathrm{m}^{3}\right)$ & 0.0002642 & cubic foot $\left(\mathrm{ft}^{3}\right)$ \\
cubic meter $\left(\mathrm{m}^{3}\right)$ & 35.31 & cubic yard $\left(\mathrm{yd}^{3}\right)$ \\
cubic meter $\left(\mathrm{m}^{3}\right)$ & 1.308 & cubic mile $\left(\mathrm{mi}^{3}\right)$ \\
cubic kilometer $\left(\mathrm{km}^{3}\right)$ & 0.2399 & acre-foot $\left(\mathrm{acre}^{3} \mathrm{ft}\right)$ \\
cubic meter $\left(\mathrm{m}^{3}\right)$ & 0.0008107 & \\
\hline
\end{tabular}

Temperature in degrees Celsius $\left({ }^{\circ} \mathrm{C}\right)$ may be converted to degrees Fahrenheit ( $\left.{ }^{\circ} \mathrm{F}\right)$ as:

$$
{ }^{\circ} \mathrm{F}=\left(1.8 \times{ }^{\circ} \mathrm{C}\right)+32 .
$$

Temperature in degrees Fahrenheit $\left({ }^{\circ} \mathrm{F}\right)$ may be converted to degrees Celsius $\left({ }^{\circ} \mathrm{C}\right)$ as:

$$
{ }^{\circ} \mathrm{C}=\left({ }^{\circ} \mathrm{F}-32\right) / 1.8 \text {. }
$$

\section{Datum}

Vertical coordinate information is referenced to the North American Vertical Datum of 1988 (NAVD 88).

Horizontal coordinate information is referenced to the North American Datum of 1983 (NAD 83). Altitude, as used in this report, refers to distance above the vertical datum.

\section{Supplemental Information}

Specific conductance is given in microsiemens per centimeter at 25 degrees Celsius $(\mu \mathrm{S} / \mathrm{cm}$ at $\left.25^{\circ} \mathrm{C}\right)$.

Concentrations of chemical constituents in water are given in milligrams per liter (mg/L). 


\section{Abbreviations}

$\begin{array}{ll}\text { Chl-a } & \text { chlorophyll a } \\ \text { CPUE } & \text { catch per unit effort } \\ \text { DF } & \begin{array}{l}\text { degrees of freedom } \\ \text { dissolved oxygen } \\ \text { DO }\end{array} \\ \text { F } & \text { analysis of variance T statistic } \\ \text { FEMRF } & \text { Fish Enhancement, Mitigation, and Research Fund } \\ \text { FERC } & \text { Federal Energy Regulatory Commission } \\ \text { GAP } & \text { USGS National GAP Analysis Program } \\ \text { GIS } & \text { geographic information system } \\ \text { GLGap } & \text { USGS Great Lakes Regional Aquatic Gap Analysis Program } \\ \text { GPP } & \text { generator powered pulsator } \\ \text { GPS } & \text { global positioning system } \\ \text { ORP } & \text { oxidation reduction potential } \\ \text { ppm } & \text { parts per million } \\ \text { SRMT } & \text { St. Regis Mohawk Tribe } \\ \text { USGS } & \text { U.S. Geological Survey }\end{array}$





\title{
Dam Removal, Connectivity, and Aquatic Resources in the St. Regis River Watershed, New York
}

\author{
By James E. McKenna, Jr., ${ }^{1}$ Kaitlin Hanak, ${ }^{1}$ Katharine DeVilbiss, ${ }^{1}$ Anthony David, ${ }^{2}$ and James H. Johnson'
}

\section{Abstract}

The decommissioning and planned removal of the Hogansburg Dam on the St. Regis River in New York has stimulated interest in the potential effects of that barrier removal on the St. Regis watershed. There will be immediate and systemic effects of the Hogansburg Dam removal, which may include inundation of habitats below the dam or dewatering of habitats above the dam, possibly affecting local fish assemblages and (or) local native mussel assemblages; and expansion of stream network connectivity, which has the potential to open a large area of the watershed to migratory aquatic species. Information was collected about biota, water quality, sediment distribution, riverbed dimensions in the vicinity of the dam, and habitat characteristics of headwater sample sites. Complete fish assemblages were collected, but species of special concern associated with the connectivity changes included, American Eel, Atlantic Salmon, Brook Trout, Eastern Sand Darter, and Lake Sturgeon. Freshwater mussels in the vicinity of the dam also were examined and may be at risk of exposure (without a rescue plan) after dam removal. Reservoir sediment will be transported downstream and will alter aquatic habitat as it moves through the system. The dam removal will open more than 440 kilometers of stream habitat to migratory species, allowing them to more easily complete their life cycles. Fish assemblages above the dam may be altered by migrating fishes, but resident Brook Trout are not expected to be adversely affected.

\section{Introduction}

Thousands of human-made dams exist within U.S. waterways, and most impede or prevent movement of fish and other aquatic organisms within and among watersheds and their components (McLaughlin and others 2013). Their presence also alters natural hydrology and can affect other aspects of lotic systems (Bednarek 2001; Hart and others 2002). Many of these barriers no longer serve the purpose for which they

${ }^{1}$ U.S. Geological Survey

${ }^{2}$ St. Regis Mohawk Tribe-Environment Division were constructed (Wildman 2013). Dam removal can alleviate the fish passage problem, but also can cause problems. The decommissioning and planned removal of the Hogansburg Dam on the St. Regis River in New York has stimulated interest in the potential effects of that barrier removal on the St. Regis watershed. The Hogansburg Dam is part of the 485 kilowatt Hogansburg Hydroelectric project, operated by Erie Boulevard Hydropower. The first Federal Energy Regulatory Commission (FERC) license to operate the dam was issued in October 1985, and the current license expires in September 2015. Built in 1930, the spillway is 75 meters (m) wide by $3.5 \mathrm{~m}$ high (Erie Boulevard Hydropower, written commun., 2012b). The dam is located near the mouth of the river and is a barrier to fish movement in this relatively large watershed $\left(2,217\right.$ square kilometers $\left.\left[\mathrm{km}^{2}\right]\right)$ that drains a portion of the Adirondack Mountains down to the St. Lawrence River. Ecologic and hydrologic conditions in the immediate vicinity of the Hogansburg Dam and in headwater habitats of the St. Regis watershed were examined, with a focus on access for migratory American Eel (Anguilla rostrata) and Atlantic Salmon (Salmo salar), drainage network connectivity to native Brook Trout (Salvelinus fontinalis) habitats, and potential effects of dam removal on threatened Eastern Sand Darters (Ammocrypta pellucida) and freshwater mussels.

This project was conducted by the U.S. Geological Survey (USGS), in cooperation with the St. Regis Mohawk Tribe (SRMT). The SRMT is interested in removal of the dam to enhance and rehabilitate the natural aquatic (and wetland) resources of their reservation and adjacent areas. Decommissioning and removal of the dam will repatriate lands within the project boundary back to the SRMT. Associated research on the St. Regis River watershed - as part of the Fish Enhancement, Mitigation, and Research Fund (FEMRF) — funded the effort to identify threatened and endangered fish species and characterize their habitats within the St. Lawrence River Valley and substantially augments the data and findings of this study (J.E. McKenna, U.S. Geological Survey, written commun., 2012). Also, products of the USGS Great Lakes Regional Aquatic Gap Analysis Project (GLGap) (McKenna and others, 2014), especially the Brook Trout species distribution model (McKenna and Johnson, 2011), aided with sampling design for this study and will benefit from the additional validation data provided by this study. 
The two major aspects of this project are the immediate and systemic effects of the Hogansburg Dam removal, which may include inundation of habitats below the dam or dewatering of habitats above the dam, possibly affecting local fish assemblages and (or) local native mussel assemblages (Stanley and others, 2002; Cooper 2011); and expansion of stream network connectivity, which has the potential to open a large area of the watershed to migratory aquatic species. Information was collected about biota, water quality, sediment distribution, riverbed dimensions in the vicinity of the dam, and habitat characteristics of headwater sample sites.

There were several species of special concern associated with the connectivity changes. American Eel is declining throughout its native range, including in the St. Lawrence River system above the Beauharnois Dam in Quebec, Canada (D.E. Dittman, U.S. Geological Survey, written commun., 2010). American Eel are catadromous (migrating between fresh and salt water as part of their life cycle), long-range migrants with extreme abilities to migrate upstream and over or around most small to moderate-sized natural (and many man-made) barriers, and occupy nearly every aquatic habitat within a watershed. Despite this impressive migratory ability, each major barrier affects their ability to move upstream and represents a potential cause of mortality. Removal of the Hogansburg Dam would improve American Eel migratory access to the St. Regis watershed.

Atlantic Salmon is thought to have been native to the St. Regis and other watersheds draining into the St. Lawrence River (Goodyear and others, 1982). The SRMT name for the hamlet of Helena, New York, located on the St. Regis River (8.2 kilometers $[\mathrm{km}]$ upstream of the of the Hogansburg Dam spillway), is Ohiekarónth:ne or "the place of the salmon," suggesting a historical location for the SRMT salmon harvest. Small-scale reintroductions of Atlantic Salmon into the St. Regis River and adjacent Little Salmon River watershed have shown that this species will persist in the system and attempt spawning migrations into the St. Regis watershed. Dam removal will make spawning habitat accessible to Atlantic Salmon, potentially allowing completion of the natural life cycle.

While the large increase in the stream network accessible to migratory species is generally considered an ecological improvement, there are possible negative effects for headwaters species presently isolated by the dam. Native Brook Trout occur in the headwaters of the St. Regis watershed, and separate populations are likely. If among these populations there is a strain that is strongly migratory, then access to the St. Lawrence River will allow for a complete migratory cycle. Overwintering Brook Trout are known to move $65-100 \mathrm{~km}$ from large rivers to upstream habitats (Curry and others, 2002); however, native resident Brook Trout may be affected by the dam removal through exposure to migratory fish species that have not previously had access to a large portion of the stream network (Stanley and Doyle, 2003). For example, although the parasitic Sea Lamprey (Petromyzon marinus) is not considered a significant problem in this part of the St. Lawrence River
Valley, expanded access to the St. Regis watershed could make more spawning and nursery habitat available to Sea Lamprey (McLaughlin and others, 2013). Other species like Walleye (Sander vitreus) and Lake Sturgeon (Acipenser fulvescens) would also likely benefit from the expanded access to this watershed (D.E. Dittman, U.S. Geological Survey, written commun., 2009; Landsman and others, 2011).

\section{Methods}

The sampling design and sample collection and analysis methods were similar to those used in the FEMRF study (J.E. McKenna, U.S. Geological Survey, written commun., 2012). The main stem and tributary habitats within $1 \mathrm{~km}$ of the Hogansburg Dam were sampled with seine, backpack, and boat electroshockers, and gillnets.

The Brook Trout species distribution model, developed for New York State by the GLGap (McKenna and others, 2015), was used to help stratify headwater sampling sites. This model predicts Brook Trout abundance potentially supported by the habitat in each stream segment of the St. Regis watershed. These predictions were used in conjunction with field observations to classify headwater streams into quality categories. In the field, the quality of these streams was assessed by substrate type, water flow, measured water temperature, and depth for feasibility of backpack electrofishing. Stream section categories for fish sampling were predicted by GLGap analysis models to be high-quality sites (11-100 Brook Trout per 100 square meters $\left[\mathrm{m}^{2}\right]$ ) and, upon field assessment, judged as highly suitable habitat; those predicted to be low quality $\left(0-10\right.$ Brook Trout per $\left.100 \mathrm{~m}^{2}\right)$ but field judged as highly suitable habitat; and those predicted to be high quality but field judged to be poor quality Brook Trout habitat. Five stream reaches from each of the previously mentioned quality categories were selected for backpack electroshock sampling. The GLGap hydrospatial framework (McKenna and others, 2015) was used to identify distinct major stream network units (subwatersheds) to ensure representativeness of the sampling design. The GLGap subwatersheds divided the St. Regis watershed into six subwatersheds; headwaters in three of these units were sampled (fig. 1). In addition, the SRMT-FEMRF work contained samples from the lowest subwatershed, as well as the lower portion of two subwatersheds covered by the headwaters work in this study.

These and other sites were evaluated for their connectivity to the watershed stream network. The dam and waterfalls database available for New York (D.E. Dittman, U.S. Geological Survey, written commun., 2010) was used in a geographic information system (GIS) to enumerate the number of known barriers below the headwater sites. Field assessment included documentation of natural (waterfalls and beaver dams) and artificial (dams and culverts) barriers. Changes in the connectivity and potential increase in accessible habitat for migratory fish resulting from dam removal also was evaluated with the GIS. 


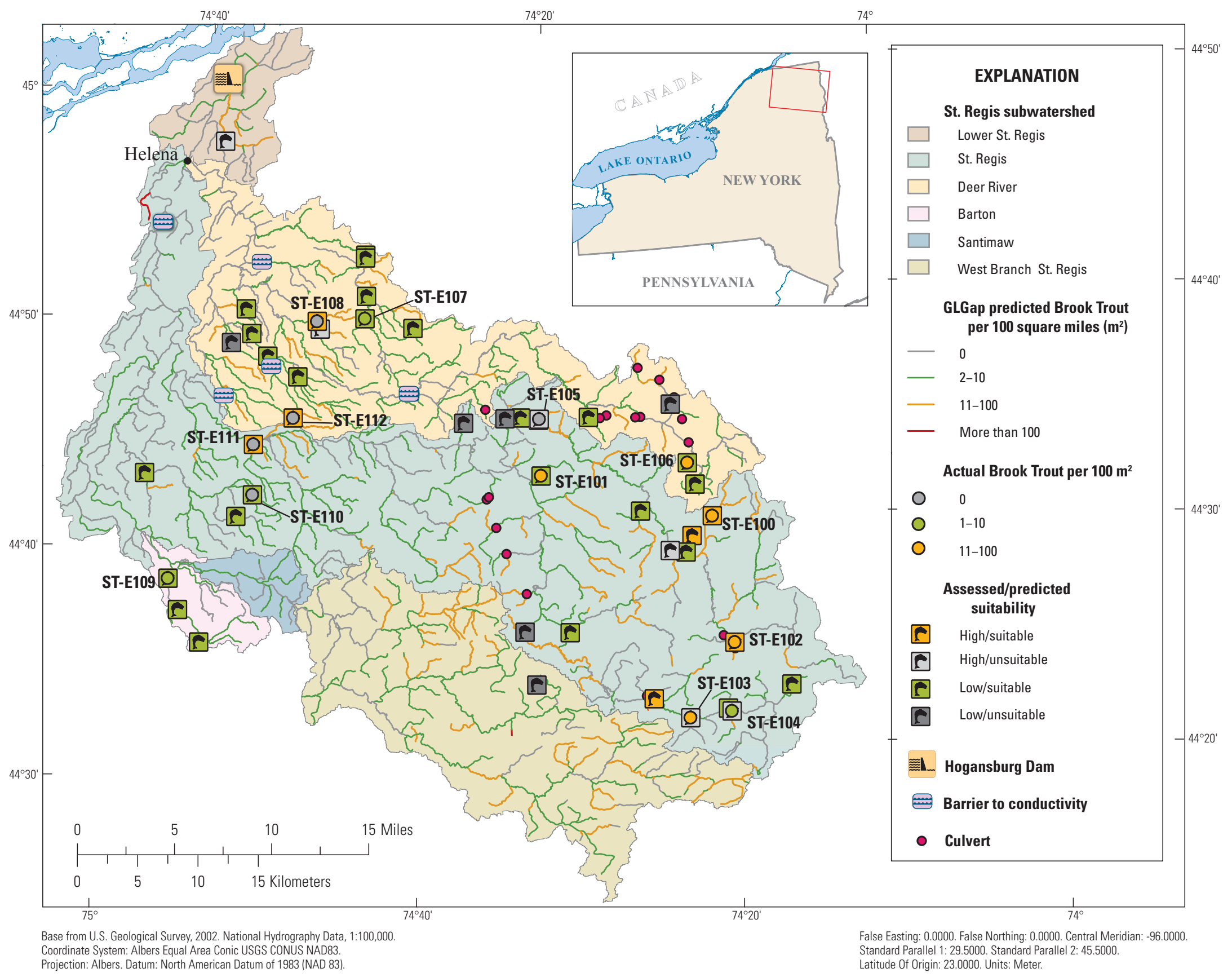

Figure 1. The St. Regis subwatersheds, observed and U.S. Geological Survey-Great Lakes Regional Aquatic Gap Analysis Project (GLGap) predicted suitability of Brook Trout habitat, and actual Brook Trout abundance at labeled sample sites. 
Headwater fish assemblages were assessed using a singlepass, backpack-electrofishing technique within a $50 \mathrm{~m}$ reach, adjusted for sampling efficiency. Multi-pass elimination (removing fish by electroshocking multiple times throughout the same stream reach) was used at two headwater sites to estimate single-pass catch efficiencies for Brook Trout and several other species (Peterson and others, 2004). Efficiency values were then used to more accurately estimate the population of fish at a site based on the number of fish captured. Standardized abundance, catch per unit effort (CPUE), was calculated as the number of fish captured divided by the area sampled for each site and divided by the efficiency for each species to estimate fish per $100 \mathrm{~m}^{2}$. The location of each sample site was recorded with a handheld global positioning system (GPS) (Garmin GPSmap 60CS), and the local habitat was characterized by measurement of water temperature, specific conductance, oxidation reduction potential (ORP), $\mathrm{pH}$, dissolved oxygen, turbidity, and chlorophyll $a$. Stream width, maximum depth, and flow were recorded every $10 \mathrm{~m}$ within the $50 \mathrm{~m}$ sample reach. The association of Brook Trout abundance with fine-scale (on-site) habitat conditions was examined using linear regression. Fish assemblage diversity was represented by richness (the number of species), evenness (the partitioning of total abundance by species), and diversity as measured by the Shannon-Weaver Information Index (Shannon and Weaver, 1949). These are common metrics that describe multispecies communities.

Samples of the conditions in the immediate vicinity of the dam were collected in a number of ways. One seine collection using a hybrid $9.1 \mathrm{~m}$ long (1/4-inch (in.) mesh wings and 1/8-in. mesh bag) (McKenna and others, 2013) was used in sandy habitat below the dam during this study. In addition, the FEMRF project (J.E. McKenna, U.S. Geological Survey, written commun., 2012) provided the following samples from the previous 2 years:

- one seine sample in soft sediment above the dam,

- one backpack shocking sample made in the lowest reach of a tributary entering the river below the dam,

- one boat electrofishing sample (using a Smith-Root kit 7.5 generator-powered pulsator on a 20 -foot Crestliner C 2070 with umbrella cathodes, yielding a 60-cycle alternating current operating at 40 percent, with output normally at 9 amperes) made in the reservoir above the dam, and

- seven gillnet samples (1-3-in. paneled monofilament mesh, $38 \mathrm{~m}$ in length, $1.8 \mathrm{~m}$ in height), two above the dam, and three below the dam.

The freshwater mussel community was qualitatively assessed by visual survey along the shore above the dam (particularly at a known muskrat midden) and by snorkeling both above and below the dam.
We also conducted a bathymetric survey using side-scan sonar (Hummingbird 997C Side-scan sonar unit) to document important characteristics of the riverbed above and below the dam. The transect above the dam started just above the safety buoys and extended upstream to the head of the reservoir. The volume of water in the reservoir was estimated by using a map of the area imported into ArcGIS and applying the three-dimensional analysis tool to create a surface of the reservoir bottom; assuming that there was a steep bank extending to $0.7 \mathrm{~m}$ on each side of the reservoir and that the bottom then sloped gently to the nearest set of side-scan sonar measurements. Side-scan depth measurements were augmented by data provided in a previous sediment survey report (Erie Boulevard Hydropower, written commun., 2012b). The full volume of the reservoir (on the day the bathymetric survey was conducted) was estimated, as well as the volume remaining after dam removal, assuming resultant water depth of $1.0 \mathrm{~m}$ or $0.5 \mathrm{~m}$ (depths typical of the areas above the reservoir). The exposed reservoir bottom resulting from the drawdown after dam removal was estimated by the difference in surface areas of the full reservoir and that of the surface area at $1.0 \mathrm{~m}$ water depth or $0.5 \mathrm{~m}$ water depth.

\section{Results}

\section{Near-Dam Conditions}

In the immediate vicinity of the dam, a total of 26 fish species were collected at 11 sample sites (fig. 2, table 1). Sample species richness ranged from 2 to 11 , with a seine collection above the dam (ST-S007) being the richest. Gillnet and boat electrofishing samples represent the deepwater component of the fish community. The boat electrofishing sample above the dam (ST-B001) was dominated by Smallmouth Bass (Micropterus dolomieu) and Brown Bullhead (Ameiurus nebulosus) with lesser abundances of Northern Pike (Esox Lucius), Rock Bass (Ambloplites rupestris), Silver Redhorse (Moxostoma anisurum), and Walleye (fig. 3). Seines represent the shallow water component of the community in the main stem, and the assemblages above and below the dam were quite different. However, there was only a single seine sample from just upstream and downstream of the dam. That component above the dam (site ST-S007) was dominated by Rosyface Shiner (Notropis rubellus) and Common Shiner (Luxilus cornutus) with lesser abundances of other minnows and a few centrarchids (sunfish and bass), while the assemblage below the dam (site ST-S100) was strongly dominated by Mimic Shiner (Notropis volucellus), with all remaining species being darters, including Eastern Sand Darter. The seine collection (ST-S100) below the Hogansburg Dam was over mostly sand substrate (95 percent) located on the downstream side of the island approximately $400 \mathrm{~m}$ below the dam. Six Eastern Sand Darters-a New York State Threatened Species-were caught, along with 108 Mimic Shiners, 1 Tessellated Darter (Etheostoma olmstedi), 1 Johnny Darter (Etheostoma nigrum), and 4 Channel Darter (Percina copelandi). 


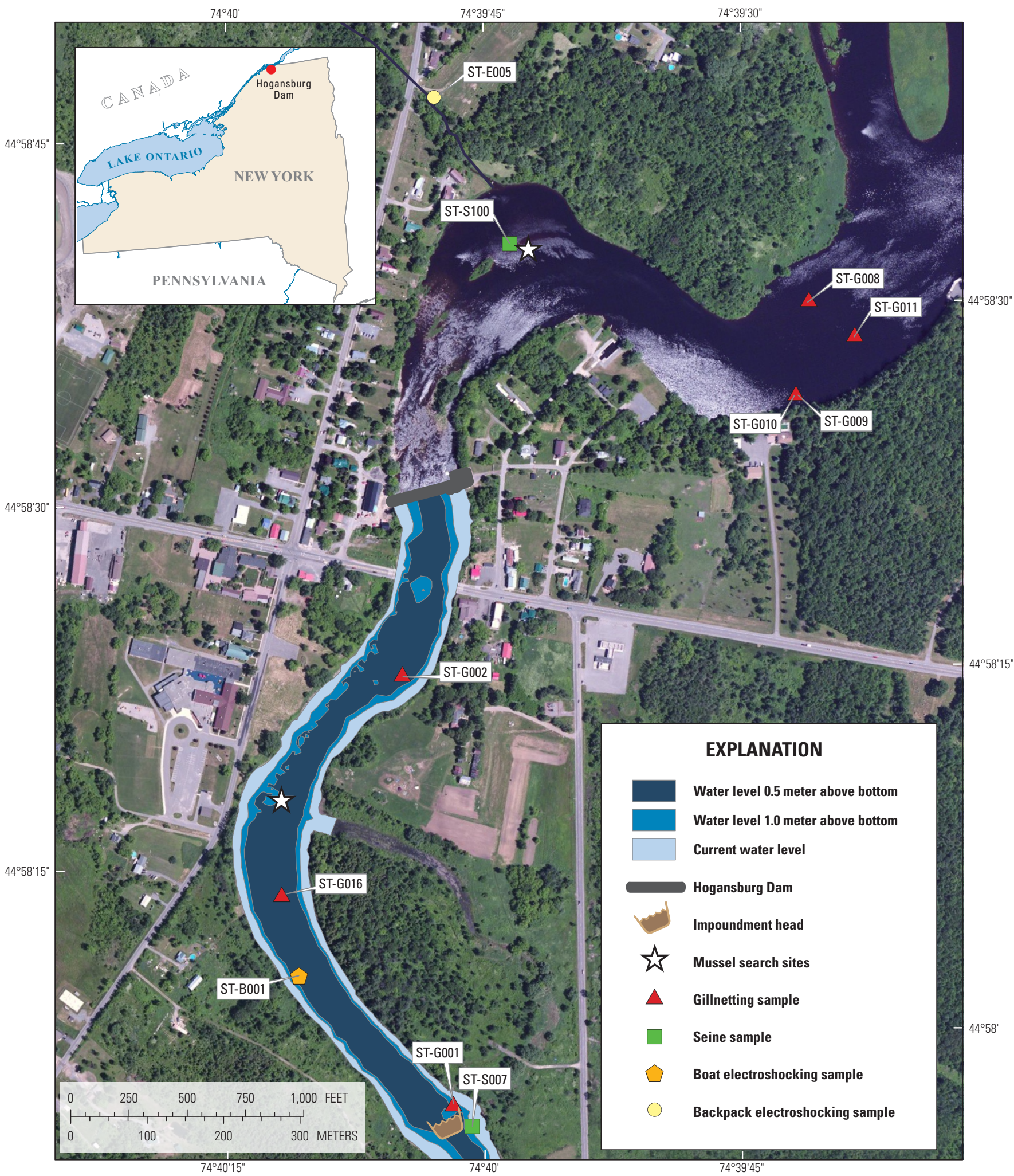

Source: Esri, DigitalGlobe, GeoEye, i-cubed, Earthstar Geographics,CNES/Airbus DS, USGS, AEX, Getmapping, Aerogrid, IGN, IGP, swisstopo, and the GIS User Community.

Coordinate System: USA Contiguous Albers Equal Area Conic USGS version. Projection: Albers. Datum: North American Datum of 1983 (NAD 83). False Easting: 0.0000. False Northing: 0.0000 Central Meridian: -96.0000. Standard Parallel 1: 29.5000. Standard Parallel 2: 45.5000. Latitude Of Origin: 23.0000. Units: Meter.

Figure 2. Sites sampled and predicted water levels in the reservoir following removal of the Hogansburg Dam, Franklin County, New York. (Collection equipment used is indicated by different color circles, and sites are labeled with assigned site code.) 
Table 1. Species richness of sample site catches near Hogansburg Dam, Franklin County, New York.

\begin{tabular}{llcc}
\hline Site code & \multicolumn{1}{c}{$\begin{array}{c}\text { Collection } \\
\text { equipment type }\end{array}$} & $\begin{array}{c}\text { Species } \\
\text { richness }\end{array}$ & $\begin{array}{c}\text { Relative location } \\
\text { from dam }\end{array}$ \\
\hline ST-B001 & Boat electrofisher & 6 & Above \\
ST-G001 & Gillnet & 4 & Above \\
ST-G002 & Gillnet & 2 & Above \\
ST-G016 & Gillnet & 2 & Above \\
ST-S007 & Seine & 11 & Above \\
ST-E005 & Backpack electrofisher & 8 & Below \\
ST-G008 & Gillnet & 2 & Below \\
ST-G009 & Gillnet & 5 & Below \\
ST-G010 & Gillnet & 4 & Below \\
ST-G011 & Gillnet & 4 & Below \\
ST-S100 & Seine & 5 & Below \\
\hline
\end{tabular}
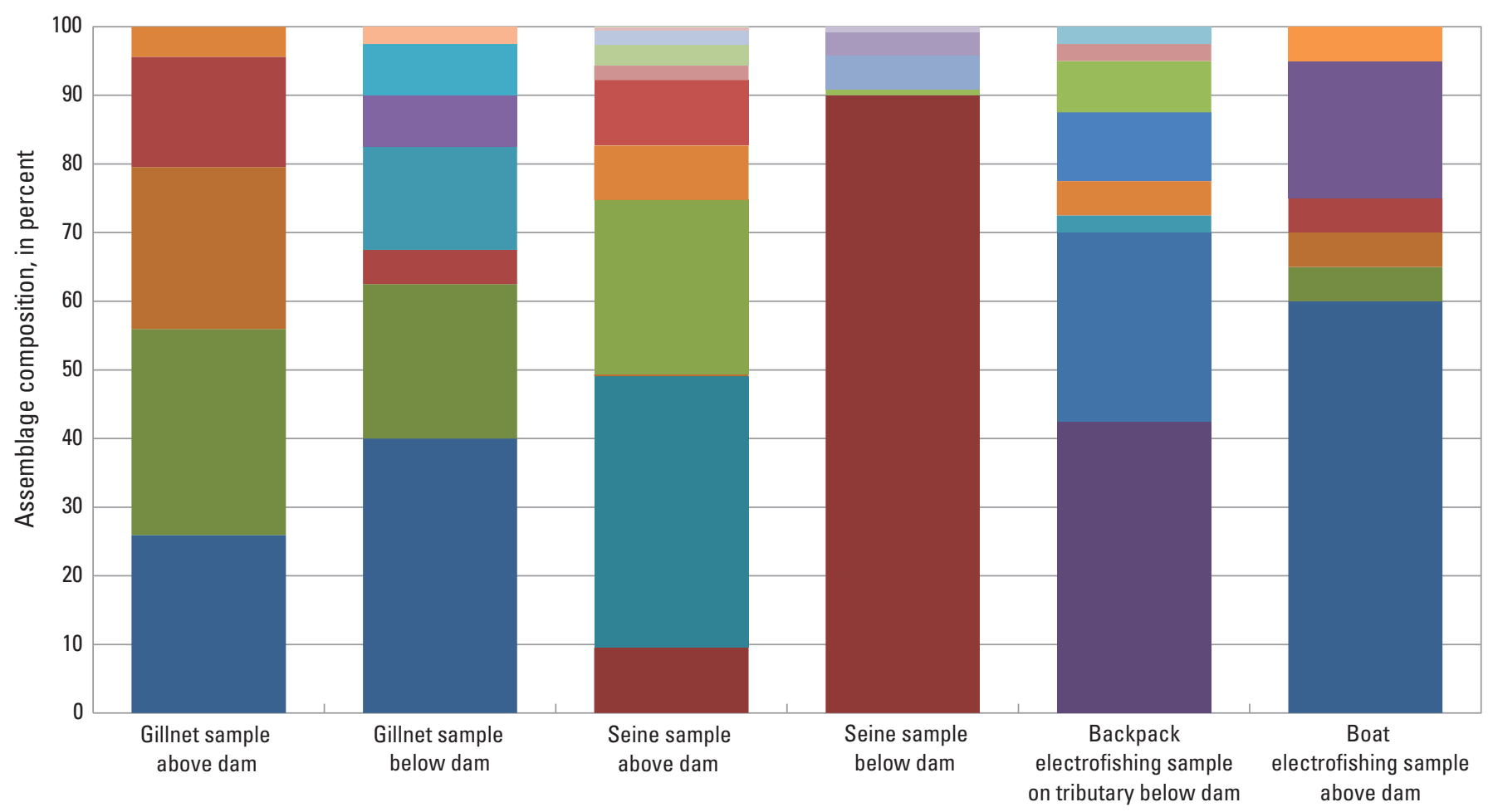

EXPLANATION
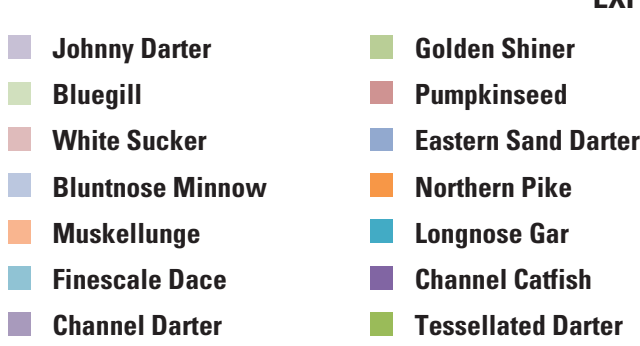

Spotfin Shiner
Central Mudminnow
Fallfish
Yellow Perch
Brown Bullhead
Common Shiner
Walleye

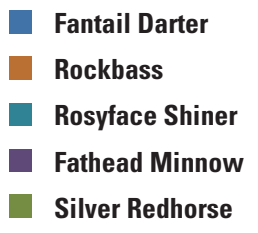

Silver Redhorse

Figure 3. Species assemblage based on sample sites near the Hogansburg Dam, Franklin County, New York. (See fig. 2 for site locations; see appendix 1 for complete species list.) 
One backpack electroshocking site (ST-E005) sampled in a tributary below the dam contained Fathead Minnow (Pimephales promelas), Fantail Darter (Etheostoma flabellare), and Central Mudminnow (Umbra limi), as well as Tessellated Darter, Fallfish (Semotilus corporalis), Finescale Dace (Chrosomus neogaeus), Yellow Perch (Perca flavescens), and Pumpkinseed (Lepomis gibbosus) in lower numbers. Only gillnet collections provided multiple samples above (sites ST-G001, G002, and G016) and below the dam (sites ST-G008, G009, G010, and G011); this community component in both areas was dominated by Smallmouth Bass and Silver Redhorse with moderate abundances of Walleye. Rock Bass and Fallfish were only abundant above the dam; Yellow Perch, Longnose Gar (Lepisosteus osseus), and Channel Catfish (Ictalurus punctatus) were found only below the dam.

Visual walking and snorkel searches for freshwater mussels were conducted approximately $400 \mathrm{~m}$ above and below the Hogansburg Dam. We found old shell remains and (or) live specimens of Eastern Elliptio (Elliptio complanata) and Yellow Lamp Mussel (Lampsilis cariosa). Mussels were found in a fairly dense bed above the dam, but they were scattered below the dam. Shells were particularly abundant at a muskrat midden $400 \mathrm{~m}$ above the dam.

\section{Measuring the Effects of Dam Removal}

The side-scan sonar survey covered an area of $0.87 \mathrm{~km}^{2}$ above the dam (table 2) and provided a map of the water depth and sediment composition within the reservoir. Results indicate that a range of approximately 117,000 to 145,000 cubic meters $\left(\mathrm{m}^{3}\right)$ of water will discharge downstream when the dam is removed, and 32 to 50 percent of the reservoir bed will be dewatered (fig. 2). The bathymetric survey was insufficient to characterize the types of sediment present or to estimate the volume of sediment above the dam. However, in 2012, a sediment characterization study was performed by Erie Boulevard Hydropower, L.P, above the Hogansburg Hydroelectric Project (Erie Boulevard Hydropower, written commun., 2012b). That study determined that the riverbed generally consisted of gravel and boulders with minimal finer sediment accumulation, and the shorelines consisted of soft clays and silts. Sediment probes determined the sediment depth ranged from 0.0 to $1.9 \mathrm{~m}$, with greater depths along the shoreline and shallower depths in the head of the reservoir. The sediment depth changes from uniform and shallow, to irregular and deep, moving from the dam to the head of the reservoir. The majority of stored sediment likely will be transported downstream during dewatering.

\section{Headwater Conditions}

Sample sites were located in three of the six subwatersheds within the St. Regis watershed (sites ST-E100-113 on fig. 1). Accessibility to headwater habitats varied among the subwatershed units. Access to stream reaches within the subwatershed containing the West Branch, as well as a large portion of the main stem subwatershed, was limited by extensive tracts of private property where permission to enter could not be acquired.

The GLGap model (McKenna and others, 2015) predicted that 63 percent of the stream network should be capable of supporting some abundance of Brook Trout. Thirteen headwater sites were sampled using backpack electroshocking; two additional high-quality sites judged to be unsuitable were not sampled because the bottom substrates were not fit for backpack electrofishing. Samples were collected from five sites that were predicted to be high quality for Brook Trout and, on field inspection, were validated as high quality. Five other sites were predicted to be poor quality, but upon inspection, appeared to be of high quality for Brook Trout and also were sampled. In addition, three sites were sampled that were predicted to be high quality, but were visually of poor quality.

The mean 1-pass efficiency (Peterson and others, 2004) of 0.61 for Brook Trout was calculated as the mean of efficiencies found at Winnebago Brook (0.69) and at Alder Brook (0.53) (table 3). Two of the other common stream species-Blacknose Dace ( Rhinichthys atratulus) and Creek Chub (Semotilus

Table 2. Estimated surface areas, volumes of water, and exposed reservoir bed above the Hogansburg Dam, Franklin County, New York.

[ $\mathrm{m}^{2}$, square meters; $\mathrm{m}^{3}$, cubic meters; $\mathrm{m}$, meters]

\begin{tabular}{lcccc}
\hline \multicolumn{1}{|c}{ Reservoir level } & $\begin{array}{c}\text { Reservoir } \\
\text { surface area } \\
\left(\mathbf{m}^{2}\right)\end{array}$ & $\begin{array}{c}\text { Reservoir } \\
\text { volume } \\
\left(\mathbf{m}^{3}\right)\end{array}$ & $\begin{array}{c}\text { Exposed reservoir bed } \\
\text { area in } \mathbf{~ m}^{2} \text { and percent } \\
\text { of total reservoir bottom } \\
\text { exposed }\end{array}$ & $\begin{array}{c}\text { Reservoir depth } \\
\text { in } \mathbf{~} \text { and percent } \\
\text { reduction of depth }\end{array}$ \\
\hline Full reservoir & 89,054 & 171,403 & 0 & 3.35 \\
Remaining water 1 m deep & 60,729 & 54,118 & 28,325 & $(0$ percent $)$ \\
Remaining water 0.5 m deep & 44,874 & 26,513 & 44,180 & 2.35 \\
& & & $(50$ percent $)$ & $(70$ percent $)$ \\
\hline
\end{tabular}


Table 3. Sampling efficiency for 1-pass electrofishing for sufficiently calculating species abundance near Hogansburg Dam, Franklin County, New York.

\begin{tabular}{llccc}
\hline \multicolumn{1}{c}{ Species } & \multicolumn{1}{c}{ Site } & Catch & Efficiency (0) & Corrected catch \\
\hline Brook Trout & Winnebago Brook & 22 & 0.69 & 23 \\
Blacknose Dace & Winnebago Brook & 17 & 0.30 & 26 \\
Brook Trout & Alder Brook & 35 & 0.53 & 39 \\
Creek Chub & Alder Brook & 136 & 0.58 & 147 \\
Blacknose Dace & Alder Brook & 83 & 0.64 & 87 \\
Fathead Minnow & Alder Brook & 6 & 0.41 & 8 \\
\hline
\end{tabular}

Table 4. Fish catch per unit effort (CPUE; standardized abundance in units of fish 100 square meters), species richness (number of species present), species diversity (ShannonWeaver information index; Shannon and Weaver, 1949), and evenness (index of the distribution of total abundance among species present) of fish assemblages in headwater sites near Hogansburg Dam, Franklin County, New York. No fish were captured at site ST-E110.

$[<$, less than $]$

\begin{tabular}{lcrccc}
\hline \multicolumn{1}{c}{ Brook Trout suitability } & Site code & CPUE & Richness & Diversity & Evenness \\
\hline High/not suitable & ST-E103 & 24.23 & 2 & 0.51 & 0.16 \\
High/not suitable & ST-E104 & 86.33 & 12 & 1.79 & 0.56 \\
High/not suitable & ST-E105 & 137.20 & 4 & 0.83 & 0.26 \\
High/suitable & ST-E100 & 32.94 & 6 & 1.12 & 0.35 \\
High/suitable & ST-E102 & 76.03 & 2 & 0.01 & $<0.01$ \\
High/suitable & ST-E108 & 300.29 & 10 & 1.41 & 0.44 \\
High/suitable & ST-E111 & 430.00 & 8 & 1.15 & 0.36 \\
High/suitable & ST-E112 & 274.58 & 5 & 1.09 & 0.34 \\
Low/suitable & ST-E101 & 378.60 & 6 & 1.40 & 0.44 \\
Low/suitable & ST-E106 & 58.90 & 1 & 0 & 0 \\
Low/suitable & ST-E107 & 88.07 & 9 & 1.37 & 0.43 \\
Low/suitable & ST-E109 & 16.01 & 3 & 0.02 & 0.01 \\
\hline
\end{tabular}

atromaculatus) — had efficiencies of 0.47 and 0.58 , respectively. Total CPUE ranged from 16 to $430 \mathrm{fish} / 100 \mathrm{~m}^{2}$ (table 4). The richness of fish assemblages ranged from 0 to 12 , and diversity was as high as 1.8. Evenness indicated relatively strong dominance of each assemblage, with all values $<0.5$, except at site ST-E104. In general, these headwater assemblages were dominated by Creek Chub, Brook Trout, and Blacknose Dace. A total of 172 Brook Trout were caught from 8 of the sites sampled. Brook Trout was the only salmonid present at sampled sites, except for site ST-E107, where 23 Brown Trout (Salmo trutta) were caught, along with 4 Brook Trout. The average number of Brook Trout caught per site was 13.23, and the average length was 8.83 centimeters $(\mathrm{cm})$.

Brook Trout model predictions matched well to observed abundances in headwaters of the St. Regis watershed (fig. 1). Of the 13 headwater sites sampled, 8 supported Brook Trout. Brook Trout were present at only one site where the habitat was predicted to be unsuitable (omission error, the fish was observed to be present, but was predicted to be absent). High abundances $(>10)$ were correctly predicted in three cases and moderate abundance (2-10) in one case. In two cases, Brook Trout were more abundant than expected (by one abundance class). At one site, Brook Trout were present, but less abundant than expected (by one abundance class); in five cases, Brook Trout were absent from where the habitat was predicted to support moderate or high abundances. The mean water temperature was 11.67 degrees Celsius $\left({ }^{\circ} \mathrm{C}\right)$ for sites where Brook Trout were present and averaged $12.97{ }^{\circ} \mathrm{C}$ for sites without Brook Trout.

The trend in observed Brook Trout abundance appeared to be most strongly related to altitude, stream width, and water temperature (fig. 4). However, multiple linear regression revealed that none of those habitat variables significantly affected Brook Trout abundance, although altitude was nearly significant $(\mathrm{p}=0.08, \mathrm{R} 2=0.37)($ table 5$)$. The $\mathrm{pH}$ of these waters also was considered because of known acid rain problems in the Adirondacks (mostly granite bedrock, providing very little acid buffering capacity), but was weak and insignificant $(\mathrm{p}=0.52, \mathrm{R} 2=0.039)$. 


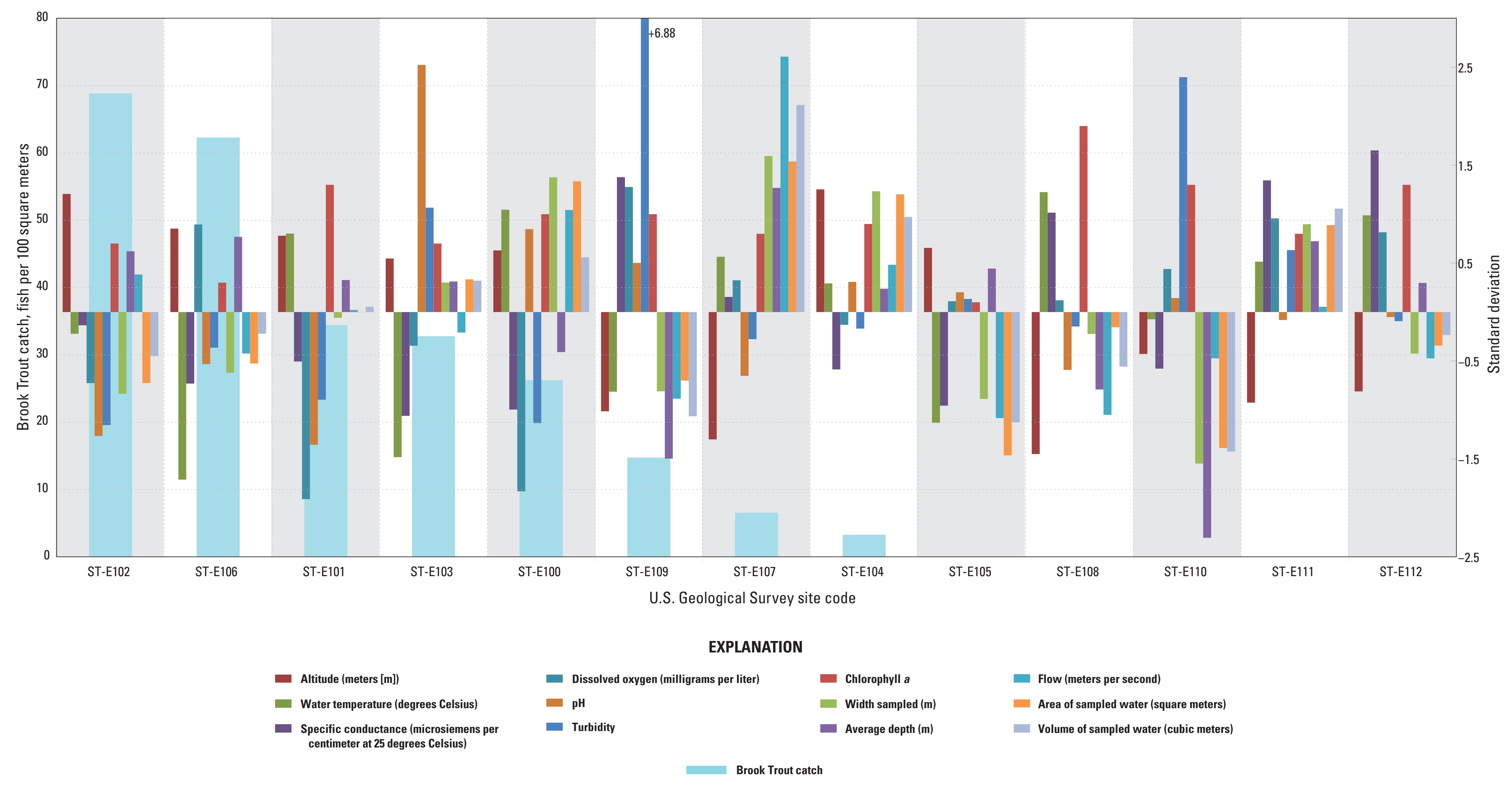

Figure 4. Habitat characteristics affecting Brook Trout abundance near Hogansburg Dam, Franklin County, New York. (See fig. 2 for site locations.) 


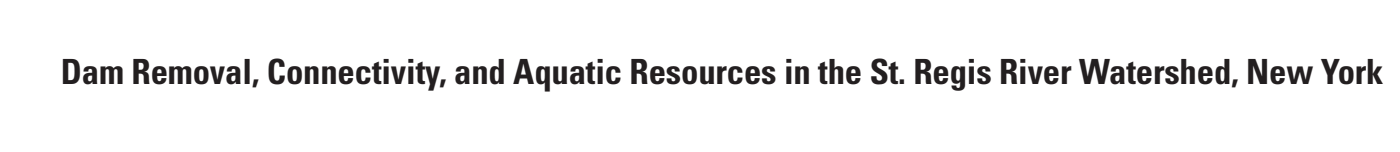


Table 5. Multiple linear regression of Brook Trout abundance as a function of altitude, water temperature, and stream size.

[t, the statistic of t-test of significance of each model parameter; $\mathrm{P}$, the probability of significance for each parameter of the model; degrees of freedom $=12$; the $\mathrm{F}$ statistic for the overall model $=2.18$; the overall model $\mathrm{P}=0.16$ ]

\begin{tabular}{lcccccc}
\hline \multicolumn{1}{c}{ Variable } & Coefficient & $\begin{array}{c}\text { Standard } \\
\text { error }\end{array}$ & $\mathbf{t}$ & $\mathbf{P}$ & $\begin{array}{c}\text { Lower } \\
\text { 95 percent }\end{array}$ & $\begin{array}{c}\text { Upper } \\
\text { 95 percent }\end{array}$ \\
\hline Intercept & 6.718 & 24.957 & 0.269 & 0.794 & -49.740 & 63.175 \\
Altitude (feet) & 0.019 & 0.010 & 1.945 & 0.084 & -0.003 & 0.041 \\
Water temperature & -1.041 & 1.724 & -0.604 & 0.561 & -4.941 & 2.859 \\
$\quad$ (degrees Celsius) & & & & & -7.474 \\
Width sampled (meter) & -0.816 & 2.943 & -0.277 & 0.788 & 5.842 \\
\hline
\end{tabular}

\section{Connectivity Assessment}

Removal of the Hogansburg Dam will open $442 \mathrm{~km}$ of stream habitat within the St. Regis watershed to fish migrating to and from the St. Lawrence River. Migrating fish will now be able to reach habitat up to the barriers to connectivity indicated in figure 1. Among the headwater sites where Brook Trout were collected, all except one are above other natural or artificial barriers and will remain isolated after the dam is removed. Many other sites that were not sampled, but are predicted to have the potential to support Brook Trout, will become accessible after the dam is removed. Although there are no known major barriers between these sites and the Hogansburg Dam, there are numerous road-crossing culverts and many beaver dams that may hinder fish passage.

Thirty-five culverts were inspected in the upper St. Regis watershed (fig. 1). Qualitative information about passability, dimensions, and location was collected, and the culverts were documented with photos and georeferenced location data. Water-quality data also were collected, although $\mathrm{pH}$ was measured at only 20 sites. Of those 20 sites, 5 had $\mathrm{pH}<7.0$ : (6.7-5.97); the $\mathrm{pH}$ at the 15 other sites ranged from 7.1 to 8.5. The majority of culverts were in good working order (33 of 35 ) with some level of fish passability. Four sites had evidence of beaver activity (nibbled trees), were poorly functioning, and (or) had blown-out dams. Six sites had obstructed upstream passage via either culvert positioning or nearby man-made structures. Seven sites had grates in place, although some had fallen over or were out of the water; several could obstruct passage, depending on fish body size.

\section{Summary and Conclusions}

During this study, the habitat in the immediate vicinity of the Hogansburg Dam on the St. Regis River in New York project area was measured and characterized, several components of the fish community in the lower St. Regis River were examined, fish assemblages in the headwaters of the watershed were examined, the amount of habitat that will become available to migratory fish when the dam is removed was estimated, and the likely changes to the system (associated with removal of this dam) were described. Changes to the system are likely to be most significant near the dam removal site - from the head of the present reservoir, downstream, possibly to the mouth of the river-while headwaters high in the watershed are unlikely to be substantially affected. Changes in local aquatic communities and fish movement are expected, as has been reported by other work on dam removals (Cooper, 2013; Kornis and others, in press).

When the dam is removed, a considerable area of the impoundment will be dewatered as the reservoir drains and, without active intervention, many freshwater mussels may die of exposure due to lower water levels in the former reservoir (Stanley and others, 2002; Cooper 2011). The amount of sediment accumulated behind the dam is reported to be relatively small (Erie Boulevard Hydropower, written commun., 2012b), but most of it is likely to be transported downstream. This may result in burial of freshwater mussels and will likely change the distribution of sediment below the dam site. That, in turn, will alter the amount and distribution of mussel and fish habitat. If the sediment transport is slow, the mussels will likely maintain proper depth in the sediment column (Galbraith and others, 2015). Eastern Sand Darters may be unaffected or may even benefit from the temporary increase in sandy habitat that is likely to result. Other aquatic species associated with rocky substratum may decline or be displaced initially. Over time, much of the sediment will be transported further downstream and eventually into the St. Lawrence River. Areas downstream of the dam site will experience more dynamic annual flood cycles from the upstream watershed. It is unclear whether or not the long-term distribution of aquatic habitats will be similar to what presently (2015) exists.

Hundreds of kilometers of stream and river habitat above the dam site will become accessible to migratory fish. This will allow species including Atlantic Salmon, American Eel, Walleye, and Lake Sturgeon to reach spawning areas and more easily complete their life cycle. An increased number of wetlands also may become available to species like Northern Pike, which spawn in flooded wetlands. Whether this expanded access will result in population changes is unknown, but genetic exchange between populations of many species above and below the dam site will be enhanced (Mahlum and others, 2014). 
Less desirable species, like Sea Lamprey, also may find more extensive spawning ground within the St. Regis watershed after the dam is removed. However, Sea Lamprey already have been discovered above the dam (Erie Boulevard Hydropower, written commun., 2012a), and this is not expected to be a substantial problem, because they are relatively uncommon (Rodger Klindt, New York State-Department of Environmental Conservation, oral commun., 2014) and are not known to spawn in St. Lawrence tributaries (Goodyear and others, 1982). Also, mortality of forage species may increase seasonally due to the migration of piscivores into the areas above the dam site (Kornis and others, in press). However, this study does not provide data to determine if such changes in mortality would significantly affect the abundances or distributions of forage species. Similarly, competition may be enhanced for some species above the dam. It is well known that Brook Trout populations tend to be displaced from larger streams and rivers when Brown Trout are introduced into their habitats. However, most headwater sites sampled in this study, where Brook Trout were present, were above other barriers and will not be exposed to new migrants; the associated fish assemblages will likely remain unaffected by the dam removal. Brown Trout already exist in sympatry (live together) with Brook Trout at sites within the stream network that will become accessible to migratory fish after the dam is removed. Other species within the newly accessible stream network also may experience increased competition from fish moving into the area from below the dam. Again, this study does not provide the data needed to evaluate the degree or existence of competition that may result. While we examined a number of potential barriers or "points of resistance" to passage upstream (poorly performing culverts and beaver dams), no measure is available of how much they will impede movement of new migrants upstream.

Headwater populations of Brook Trout appeared to be healthy in many habitats, and no particular local habitat variable (including $\mathrm{pH}$ ) explained their abundance. The relations between Brook Trout abundance and habitat variables may be non-linear, and multiple interacting affects at a variety of spatial scales are likely to influence them (McKenna and Johnson, 2011). The match between observed Brook Trout abundances and model predictions helped to generally validate the model; only a single omission error occurred. This model emphasized warm summer air temperatures, but low water temperatures; summer precipitation; and percentage of land used for agriculture. The comparison also revealed a number of sites where habitat conditions may be degraded below the potential for those streams. The five sites without Brook Trout (where they were expected to be present, based on the model) could be examined to determine if they would be good candidates for restoration to improve Brook Trout abundance.

\section{Limitations}

This study provides valuable new information about the role that the Hogansburg Dam plays in the ecology of the St. Regis watershed and what changes may occur when that barrier is removed. However, this initial study collected only a few samples, particularly near the dam, and only during the summer (September). The species observed in the vicinity of the dam are relatively common, but more extensive sampling may reveal the presence of less common species. Other fish and habitat samples have been collected in association with related studies (D.E. Dittman, U.S. Geological Survey, written commun., 2009; Erie Boulevard Hydropower, written commun., 2012a) and routine collections by the New York State-Department of Environmental Conservation (New York State-Department of Environmental Conservation, written commun., 2002). Use of these data and analyses of broadscale and local habitats together (McKenna and others, 2006; McKenna and Johnson, 2011) could reveal more about Brook Trout in the headwaters and species communities in the vicinity of the dam.

More extensive habitat surveys would contribute to better predictions of change caused by removal of the dam. For example, our estimates from the bathymetric survey are crude. The assumptions should be validated with a more extensive survey of reservoir depths. More accurate estimates of stored sediment volume also would help project the effects of sediment transport on aquatic organisms downstream of the dam and would inform the dam removal process.

It is clear that an extensive portion of the St. Regis River watershed stream network will become accessible to migratory fish, including species like American Eel, Atlantic Salmon, Walleye, and Sea Lamprey, when the Hogansburg Dam is removed. However, the increased amount of spawning, nursery, and feeding habitat is not known, nor are the number and locations of smaller impediments to upstream migration. Additional sampling for these small barriers and habitat conditions within the watershed would help to better understand the ecological changes associated with the dam removal (Januchowski-Hartley and others, 2013). A cursory evaluation of road crossing during this study indicates that more fish passage-friendly and (or) beaver resistant culverts could greatly increase connectivity in the basin (Bigford, 2015).

Post-removal evaluation is critical to determining the value and effects of removing the Hogansburg Dam. Monitoring of fish movements, for game fish and other species, past the dam removal site would greatly improve our understanding of the importance and extent of fish migrations in the St. Regis River system. Extensive monitoring will allow detection of migratory fish moving far into the watershed and may indicate 
habitat use by American Eel, returns of Atlantic Salmon, and use of newly accessible esocid (Muskellunge, Esox masquinongy, and Northern Pike) spawning habitats. Evaluation of fish assemblages found above and below the dam site at various times after the removal is needed to understand the aquatic community changes associated with the barrier removal (Kanehl and others, 1997). Repeated sampling in the headwaters will help to determine if any changes could be associated with the dam removal. Changes in the distribution of fish habitats below the dams should be documented and monitored over the time it takes for the sediment that had been stored above the dam to move out of the system. Such monitoring will reveal significant habitat alterations and allow evaluation of ecological changes during the time period in which dam removal effects are greatest. A relocation plan for freshwater mussels likely exposed by the drawdown could be considered and may be required for compliance with the State 401 Water Quality Certification. This study and any subsequent investigations can help support management decisions and extend our knowledge of the role of artificial barriers and effects of their removal.

\section{Future Research Needs}

- More extensive habitat surveys for better predictions of changes in aquatic communities and habitats caused by dam removal.

- Collect baseline data and generate habitat suitability information (HSI) for migratory species, mussels, and other aquatic macroinvertebrates that will benefit from dam removal including American Eel, Atlantic Salmon, Walleye, Sea Lamprey, and Lake Sturgeon; assessment of invasive species effects also should be emphasized.

- Identify and prioritize fish passage bottlenecks for migratory species above the dam that are associated with poor road culverts, beaver activity, etc.

- Use of existing data and landscape models and tools to predict changes to Brook Trout in the headwaters and species communities in the vicinity of the dam.

\section{References Cited}

Bednarek, A.T., 2001, Undamming rivers-A review of the ecological impacts of dam removal: Environmental Management, v. 27 , no. 6 , p. 803-814.

Bigford, T.E., 2015, Culverts as culprit and conservation choice: Fisheries, v. 40, no. 1, p. 5.

Cooper, J.E., 2011, Unionid mussel mortality from habitat loss in the Salmon River, New York, following dam removal: Advances in Environmental Research, v. 14, p. 351-364.

Cooper, J.E., 2013, Effect of dam removal on aquatic communities in the Salmon River, New York-Final report 2013 (rev. October 2014): Constantia, N.Y., Cooper Environmental Research, Project \#2005-0129-013, 58 p., accessed July 14, 2015, at http://cooperenvironmentalresearch.com/ resources/2012FinalReportREV.pdf.

Curry, R.A., Sparks, David, and van de Sande, Jacob, 2002, Spatial and temporal movements of a riverine Brook Trout population: Transactions of the American Fisheries Society, v. 131 , no. 3 , p. 551-560.

Galbraith, H.S., Blakeslee, C.J., and Lellis, W.A., 2015, Behavioral responses of freshwater mussels to experimental dewatering: Freshwater Science, v. 34, no. 1, p. 42-52.

Goodyear, C.D., Edsall, T.A., Ormsby Dempsey, D.M., Moss, G.D., and Polanski, P.E., 1982, Atlas of the spawning and nursery areas of Great Lakes fishes_-Volume XII, St. Lawrence River: Washington, D.C., U.S. Fish and Wildlife Service, FWS/OBS-82/52, 34 p.

Hart, D.D., Johnson, T.E., Bushaw-Newton, K.L., Horwitz, R.J., Bednarek, A.T., Charles, D.F., Kreeger, D.A., and Velinsky, D.J., 2002, Dam removal-Challenges and opportunities for ecological research and river restoration: BioScience, v. 52, no. 8, p. 669-682.

Januchowski-Hartley, S.R., McIntyre, P.B., Diebel, Matthew, Doran, P.J., Infante, D.M., Joseph, Christine, and Allan, J.D., 2013, Restoring aquatic ecosystem connectivity requires expanding inventories of both dams and road crossings: Frontiers in Ecology and the Environment, v. 11, no. 4, p. 211-217.

Kanehl, P.D., Lyons, John, and Nelson, J.E., 1997, Changes in the habitat and fish community of the Milwaukee River, Wisconsin, following removal of the Woolen Mills Dam: North American Journal of Fisheries Management, v. 17, no. 2, p. 387-400.

Kornis, M.S., Weidel, B.C., Powers, S.M., Cline, T., Diebel, M., Fox, J., and Kitchell, J.F., in press, Partial biotic homogenization following removal of an impassable barrier separating two disparate stream fish communities: Aquatic Sciences. 
Landsman, S.J., Nguyen, V.M., Gutowsky, L.F.G., Gobin, J., Cook, K.V., Binder, T.R., Lower, N., Mclaughlin, R.L., and Cooke, S.J., 2011, Fish movement and migration studies in the Laurentian Great Lakes-Research trends and knowledge gaps: Journal of Great Lakes Research, v. 37, no. 2, p. 365-379.

Mahlum, Shad; Kehler, D.G.; Cote, David; Wiersma, Y.F., and Stanfield, Les, 2014, Assessing the biological relevance of aquatic connectivity to stream fish communities: Canadian Journal of Fisheries and Aquatic Sciences, v. 71, no. 12, p. $1852-1863$.

McKenna, J.E., Jr., and Johnson, J.H., 2011, Landscape models of Brook Trout abundance and distribution in lotic habitat with field validation: North American Journal of Fisheries Management, v. 31, no. 4, p. 742-756.

McKenna, J.E., Jr., McDonald, R.P., Castiglione, C., Morrison, S., Kowalski, K., and Passino-Reader, D., 2006, A broadscale fish-habitat model development process, Genesee Basin, New York, in Hughes, R.M., Wang, L., and Seelbach, P.W., eds., Proceedings of the Symposium on Landscape Influences on Stream Habitats and Biological Assemblages: Bethesda, Md., American Fisheries Society, Symposium 48, p. 533-554.

McKenna, J.E., Jr., Schaeffer, J.S., Stewart, J.S., and Slattery, M.T., 2015, Development of a spatially universal framework for classifying stream assemblages with application to conservation planning for Great Lakes lotic fish communities: Restoration Ecology, v. 23, no. 2, p. 167-178.
McKenna, J.E.; Waldt, E.M.; Abbett, Ross; David, Anthony; and Snyder, James, 2013, Hybrid seine for full fish community collections: Journal of Freshwater Ecology, v. 28, no, 1, p. $125-131$.

McLaughlin, R.L., Smyth, E.R.B., Castro-Santos, T., Jones, M.L., Koops, M.A., Pratt, T.C., and Vélez-Espino, LuisAntonio, 2013, Unintended consequences and trade-offs of fish passage: Fish and Fisheries, v. 14, no. 4, p. 580-604.

Peterson, J.T., Thurow, R.F., and Guzevich, J.W., 2004, An evaluation of multipass electrofishing for estimating the abundance of stream-dwelling salmonids: Transactions of the American Fisheries Society, v. 133, p. 462-475.

Shannon, C.E., and Weaver, Warren, 1949, The mathematical theory of communication: Urbana, Ill., University of Illinois Press, $117 \mathrm{p}$.

Stanley, E.H., and Doyle, M.W., 2003, Trading off-The ecological effects of dam removal: Frontiers in Ecology and the Environment, v. 1, no. 1, p. 15-22.

Stanley, E.H., Luebke, M.A., Doyle, M.W., and Marshall, D.W., 2002, Short-term changes in channel form and macroinvertebrate communities following low-head dam removal: Journal of the North American Benthological Society, v. 21, no, 1, p. 172-187.

Wildman, Laura, 2013, Dam removal-A history of decision points: Reviews in Engineering Geology, v. 21, p. 1-10. 


\section{Appendix 1. Fish Species Code Definitions}

\begin{tabular}{ll}
\hline \multicolumn{1}{c}{ Common name } & \multicolumn{1}{c}{ Scientific name } \\
\hline Brown Bullhead & Ameiurus nebulosus \\
\hline Bluegill & Lepomis macrochirus \\
\hline Bluntnose Minnow & Pimephales notatus \\
\hline Brook Trout & Salvelinus fontinalis \\
\hline Brown Trout & Salmo trutta \\
\hline Central Mudminnow & Umbra limi \\
\hline Channel Darter & Percina copelandi \\
\hline Common Shiner & Luxilus cornutus \\
\hline Eastern Sand Darter & Ammocrypta pellucida \\
\hline Fallish & Semotilus corporalis \\
\hline Fantail Darter & Etheostoma flabellare \\
\hline Fathead Minnow & Pimephales promelas \\
\hline Finescale Dace & Phoxinus neogaeus \\
\hline Golden Shiner & Notemigonus crysoleucas \\
\hline Johnny Darter & Etheostoma nigrum \\
\hline Mimic shiner & Notropis volucellus \\
\hline Muskellunge & Esox masquinongy \\
\hline Northern Pike & Esox lucius \\
\hline Pumpkinseed & Lepomis gibbosus \\
\hline Rock Bass & Ambloplites rupestris \\
\hline Rosyface Shiner & Notropis rubellus \\
\hline Smallmouth Bass & Micropterus dolomieu \\
\hline Spotfin Shiner & Cyprinella spiloptera \\
\hline Silver Redhorse & Moxostoma anisurum \\
\hline Tessellated Darter & Etheostoma olmstedi \\
\hline Walleye & Sander vitreus \\
\hline White Sucker & Catostomus commersonii \\
\hline Yellow Perch & Perca flavescens \\
\hline & \\
\hline
\end{tabular}




